\title{
Bone morphogenetic protein 2 inhibits FSH responsiveness in hen granulosa cells
}

\author{
Morgan J Haugen and A L Johnson ${ }^{1}$ \\ Department of Biological Sciences, The University of Notre Dame, Notre Dame, Indiana 46556, USA and \\ ${ }^{1}$ Department of Poultry Science and Center for Reproductive Biology and Health, The Pennsylvania State University, \\ 227 Henning Building, University Park, Pennsylvania 16802, USA
}

Correspondence should be addressed to A L Johnson; Email: alj14@psu.edu

\begin{abstract}
Prior to follicle selection into the preovulatory hierarchy, hen granulosa cells from prehierarchal follicles remain undifferentiated, as defined in part by the virtual absence of $L H R$ mRNA expression and inability to produce progesterone. It has previously been proposed that prior to follicle selection, granulosa cells are actively maintained in an undifferentiated state by epidermal growth factor receptor ligands (EGFRL) signaling via the MAP kinase/extracellular regulated kinase pathway. Moreover, there is recent evidence that EGFRL/MAP kinase signaling modulates FSH receptor (FSHR) transcription, in part, via inhibitor of differentiation/DNA-binding (ID) proteins. In the present studies with undifferentiated granulosa, recombinant human ( $r$ ) bone morphogenetic protein 2 (BMP2) induced the phosphorylation of SMAD1/5/8, and blocked transforming growth factor $\beta$ and FSH-induced FSHR expression and progesterone production. Significantly, BMP2 rapidly induced mRNAs encoding betacellulin and EGF, plus ID proteins (ID1, ID3, and ID4). Alternatively, the bioactivity of BMPs can be modulated by one or more BMP antagonists, including noggin (NOG). NOG mRNA is expressed by both hen granulosa and theca tissues from prehierarchal follicles. Pretreatment of cultured granulosa with rh NOG reversed both the stimulatory effects of BMP2 on ID1, ID3, and ID4 expression and the inhibitory effects of BMP2 on FSHR mRNA levels and progesterone production. Collectively, these data provide evidence that prior to follicle selection, BMP2 signaling contributes toward maintaining granulosa cells in an undifferentiated state. The actions of BMP2 are, at least in part, mediated indirectly via enhanced EGFRL expression and ERBB receptor-mediated MAP kinase signaling, and can be modulated by the autocrine/paracrine production of NOG. Reproduction (2010) $\mathbf{1 4 0} 551-558$
\end{abstract}

\section{Introduction}

In the avian ovary, the selection of a single follicle per day into the preovulatory hierarchy occurs from a small cohort of prehierarchal follicles. In the laying hens, follicles within this cohort measure $6-8 \mathrm{~mm}$ in diameter, and generally consist of some $6-15$ in number. Prior to follicle selection, the hen granulosa cells from prehierarchal follicles remain undifferentiated, as defined by elevated levels of FSHR mRNA expression, the virtual absence of $L H R$ mRNA expression, and an inability to produce progesterone. It has been previously demonstrated that members of the transforming growth factor $\beta$ (TGFB) superfamily, TGFB, and activin A, alone and in combination with $\mathrm{FSH}$, promote FSHR mRNA expression and initiate $\mathrm{FSH}$-induced progesterone production in undifferentiated granulosa cells from prehierarchal follicles (Woods \& Johnson 2005). Moreover, it has been established that epidermal growth factor receptor ligand (EGFRL) signaling via the MAP kinase/ extracellular regulated kinase (ERK) pathway can completely block agonist-induced responses to $\mathrm{FSH}$.
Previous studies with hen prehierarchal follicles have determined that the EGFRLs, betacellulin (BTC), and EGF are produced in an autocrine fashion by the granulosa layer, whereas TGFA is produced by the theca layer and acts on the adjacent granulosa in a paracrine fashion (Woods et al. 2005, 2007). Conversely, inhibition of MAP kinase/ERK signaling (e.g. using selective MAP kinase pathway inhibitors) promotes FSHR expression, and when combined with FSH treatment, potentiates FSHR expression plus promotes granulosa cell differentiation (Woods \& Johnson 2005). Together, these findings have formed the basis of a working model predicting that active MAP kinase signaling precludes premature differentiation of granulosa cells in all prehierarchal follicles except the follicle destined for selection (Johnson \& Woods 2009). Accordingly, granulosa cell differentiation associated with preovulatory follicle growth is proposed to occur only following selective release from inhibitory MAP kinase/ERK signaling. Established characteristics of differentiated hen granulosa cells from follicles subsequent to selection include enhanced capacity for FSH-induced cAMP formation 
(Tilly et al. 1991), significant up-regulation of LH receptor expression and LH responsiveness (Johnson et al. 1996), STAR protein expression (Johnson \& Bridgham 2001), and cytochrome P450 side chain cleavage enzyme activity (Li \& Johnson 1993), together with a greatly enhanced capacity for progesterone production.

Although several endocrine/paracrine/autocrine factors and associated signaling pathways have been implicated in regulating FSHR levels in the hen granulosa cells, much less is known about transcriptional processes associated with FSHR expression. Inhibitor of differentiation/DNA-binding (ID) proteins represent members of the basic helix-loop-helix (bHLH) superfamily of transcription factors (TFs) that lack a DNAbinding domain. Thus, ID proteins can act as negative antagonists of transcription by dimerizing with bHLH TFs to prevent their binding with a promoter E-box element (Ruzinova \& Benezra 2003). Importantly, it has been reported that activation of the rat $F S H R$ promoter is dependent upon a functional E-box element (Heckert 2001). More recently, levels of ID proteins (ID1, ID3, ID4, and ID2) in the hen granulosa cells were found to be regulated by BTC (acting in a paracrine/autocrine fashion) and TGFA (acting in a paracrine fashion), and reflective of FSHR mRNA expression (Johnson et al. 2008a). Specifically, elevated levels of ID1, ID3, and ID4 in granulosa from prehierarchal follicles are associated with decreased levels of FSHR, whereas enhanced expression of ID2 is associated with enhanced FSHR expression and $\mathrm{FSH}$ responsiveness.

Within the mammalian ovary, critical roles have been established for several bone morphogenetic protein (BMP) family members in relation to initial follicle recruitment (e.g. GDF9, Dong et al. 1996), follicle selection (e.g. BMP15, Galloway et al. 2000), and FSHR expression and/ or FSH responsiveness (e.g. BMP15, Otsuka et al. 2001; BMP6, Shi et al. 2009). Several BMP family members, together with their known receptors, are expressed in hen preovulatory follicles (Onagbesan et al. 2003, Al-Musawi et al. 2007). These published findings have been confirmed during the course of our studies, and have been extended to include prehierarchal follicles (1-12 mm diameter). In particular, BMP2 mRNA together with mRNAs encoding BMPR1 (subtypes ALK2, ALK3, and ALK6) and BMPR2 is expressed in the hen granulosa and theca tissues from prehierarchal follicles.

There is currently little information regarding mechanisms that regulate the tissue-specific expression of BMPs or their receptors within the ovary. It is, however, generally recognized that the extracellular activity of TGFB superfamily proteins can be modified by one or more antagonists. These secreted proteins selectively bind various TGFB family members and prevent their interaction with BMP receptors. Among the mammalian BMP antagonists expressed in various ovarian tissues are included gremlin, protein related to DAN and cerberus (PRDC), chordin, follistatin, and noggin (NOG; Sudo et al. 2004, Knight \& Glister 2006). Expression profiles and proposed functions for follistatin in the hen follicles have previously been discussed (Davis et al. 2001, Lovell et al. 2003). To our knowledge, however, there have been no reports to date regarding the expression or activity of the BMP-specific antagonist, NOG, in the avian ovary.

To date, published studies designed to elucidate a role for BMPs in the avian ovary have been limited to cultures of differentiated granulosa cells collected from the three to four largest preovulatory (e.g. post-selection) follicles (Onagbesan et al. 2003, Al-Musawi et al. 2007). In our laboratory, work has been initiated to establish a role for BMPs in the organization and maintenance of the prehierarchal cohort of avian follicles from which follicle selection reoccurs on a daily basis. Unlike in mammals where subdominant (non-selected) follicles undergo atresia each cycle, the maintenance and viability of this prehierarchal cohort in birds are critical to enable daily follicle selection and ovulation for the duration of a clutch. The present study focused on a role for BMP2 and its associated signaling mechanisms in modulating FSHR mRNA expression and $\mathrm{FSH}$ responsiveness in granulosa cells from this cohort of prehierarchal follicles.

\section{Results}

\section{BMP2 mRNA expression in ovarian follicles}

$B M P 2$ cDNA was amplified from the granulosa and theca tissues from prehierarchal follicles $(6-8 \mathrm{~mm}$ diameter) and the second largest preouvlatory (F2) follicles (Fig. 1). These results provide evidence that BMP2 may act as an autocrine or paracrine factor in the hen ovary.

\section{BMP2 inhibition of FSHR expression and FSH responsiveness (progesterone production)}

Treatment of undifferentiated granulosa cells with BMP2 at doses of 10 and $50 \mathrm{ng} / \mathrm{ml}$ for 30 min enhanced the phosphorylation of SMAD1/5/8 (Fig. 2, inset). As previously established and confirmed herein, a 20-min treatment with BTC $(10 \mathrm{ng} / \mathrm{ml})$ promoted significant

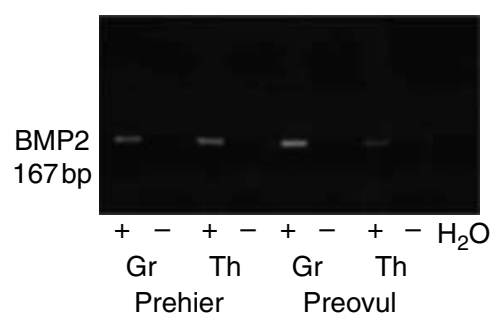

Figure 1 BMP2 cDNA amplified from granulosa (Gr) and theca (Th) tissues from prehierarchal (Prehier) follicles of $6-8 \mathrm{~mm}$ diameter and preovulatory (Preovul) follicles. + , reverse transcriptase; - , without reverse transcriptase; and $\mathrm{H}_{2} \mathrm{O}$, water blank. 
phosphorylation of ERK (Woods et al. 2005). By contrast, BMP2 $(10 \mathrm{ng} / \mathrm{ml})$ failed to promote any significant increase in levels of phosphorylated ERK within this time frame (data not shown). These results provide evidence for initial BMP2 signaling via the SMAD1/5/8 pathway. Whereas a 24-h culture of undifferentiated granulosa cells with TGFB alone or in combination with FSH promoted FSHR expression (Fig. 2A) and a very modest quantity of progesterone production (Fig. 2B), a 3-h pretreatment with BMP2 $(10 \mathrm{ng} / \mathrm{ml})$ completely blocked these stimulatory effects.

\section{BMP2-induced EGFRL and ID protein isoform mRNA expression}

Treatment of undifferentiated granulosa cells from prehierarchal follicles with BMP2 $(10 \mathrm{ng} / \mathrm{ml})$ for $20 \mathrm{~min}$ and for $3 \mathrm{~h}$ increased both EGF and BTC mRNA expression (Fig. 3). In addition, BMP2 treatment promoted expression of ID1,ID3, and ID4 mRNA after a 3-h treatment, but not after a 20-min treatment (Fig. 4).
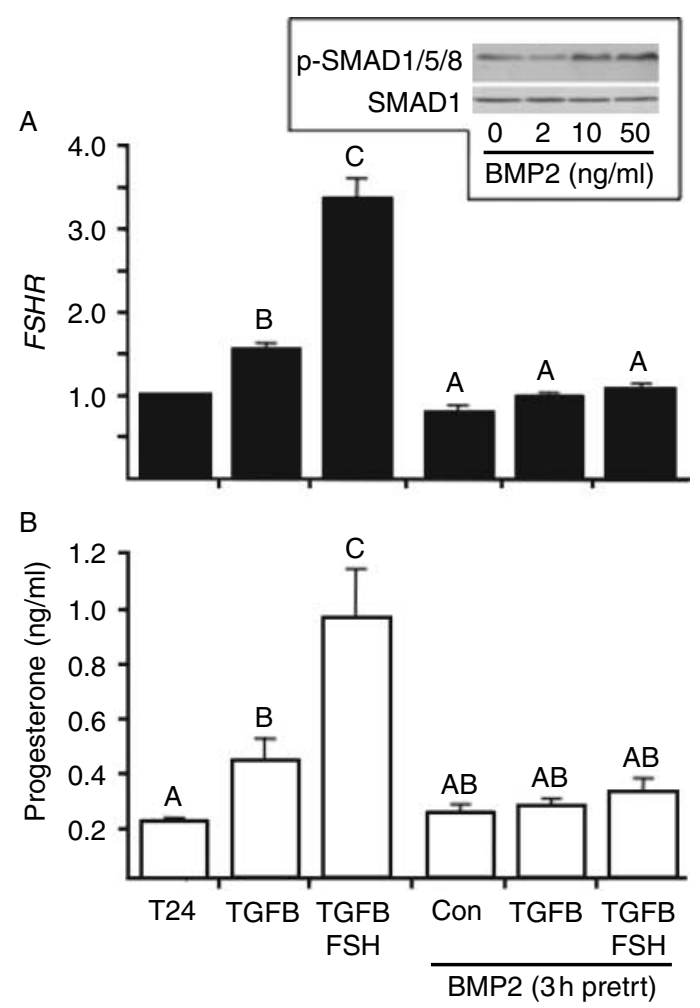

Figure $2 F S H R$ mRNA expression (A) and progesterone levels (B) from undifferentiated granulosa cells precultured for $3 \mathrm{~h}$ in the absence or presence of BMP2 $(10 \mathrm{ng} / \mathrm{ml})$, and then cultured with TGFB1 $(10 \mathrm{ng} / \mathrm{ml})$ and FSH $(100 \mathrm{ng} / \mathrm{ml})$ for an additional $21 \mathrm{~h}$. FSHR is expressed as fold difference compared to control cultured (T24) cells. Data represent the mean \pm s.E.M. from four replicate experiments. A, B, and C; $P<0.01$. Inset represents SMAD1/5/8 phosphorylation (p-SMAD) in undifferentiated granulosa cells after treatment with 2,10 , or $50 \mathrm{ng} \mathrm{BMP} 2 / \mathrm{ml}$ for $30 \mathrm{~min}$. This experiment was repeated once with similar results.

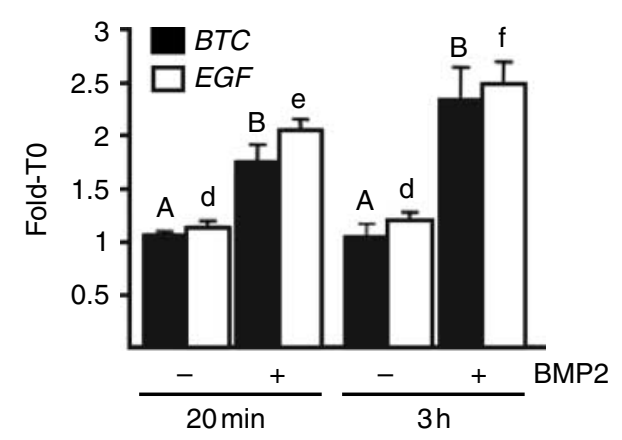

Figure $3 \mathrm{BMP} 2$ treatment $(+; 10 \mathrm{ng} / \mathrm{ml})$ for $20 \mathrm{~min}$ or for $3 \mathrm{~h}$ increased betacellulin (BTC) and epidermal growth factor (EGF) mRNA expression levels compared with control cultured (-) granulosa cells from prehierarchal follicles. Data are expressed as mean fold difference \pm s.E.M. compared to uncultured (T0) cells (not shown). $N=3$ replicate experiments. A, B and d, e, f: $P<0.05$.

ID2 mRNA levels were significantly decreased by a 3-h treatment with BMP2. These findings indicate that under these culture conditions, BMP2-induced BTC and EGF expression precedes changes in $I D$ mRNA expression.

\section{$B M P 2$ actions are dependent upon ERBB receptor tyrosine kinase activity}

In light of the finding that BMP2 induced autocrine EGF and BTC mRNA expression, it was hypothesized that the inhibitory effects of BMP2 on FSHR expression could be indirectly mediated by EGFRL via ERBB/MAP kinase signaling. Accordingly, the ability of the selective ERBB1/ERBB4 receptor tyrosine kinase inhibitor, AG1478, to block the inhibitory effects of BMP2 on FSHR mRNA expression was evaluated. In fact, pretreatment of cultured cells with AG1478 prevented the ability of BMP2 to inhibit TGFB + FSH-induced FSHR (Fig. 5). These results suggest that the differentiation-inhibiting effects of BMP2 in the hen granulosa cells occur, at least in part, via inhibitory MAP kinase signaling.

\section{BMP2 activity is antagonized by NOG}

NOG mRNA was readily amplified from the granulosa and theca tissues collected from the prehierarchal follicles of 3-5 and 6-8 $\mathrm{mm}$ diameter, as well as from the most recently selected $(9-12 \mathrm{~mm}$ ) follicle (Fig. 6A). The potential regulatory activity of NOG is indicated by the ability of recombinant human (rh) NOG pretreatment to prevent BMP2-mediated induction of ID1, ID3, and ID4 mRNA expression in a dose-dependent fashion (Fig. 6B). Significantly, a $25 \mathrm{ng} / \mathrm{ml}$ dose of BMP2 (compared with $10 \mathrm{ng} \mathrm{BMP/ml;} \mathrm{Fig.} \mathrm{1)} \mathrm{decreased} \mathrm{both}$ basal expression of FSHR and basal (unstimulated) levels of progesterone production (Fig. 7). Preculture with increasing doses of NOG reversed the BMP2-mediated reduction in FSHR mRNA expression, and restored basal levels of progesterone production. 

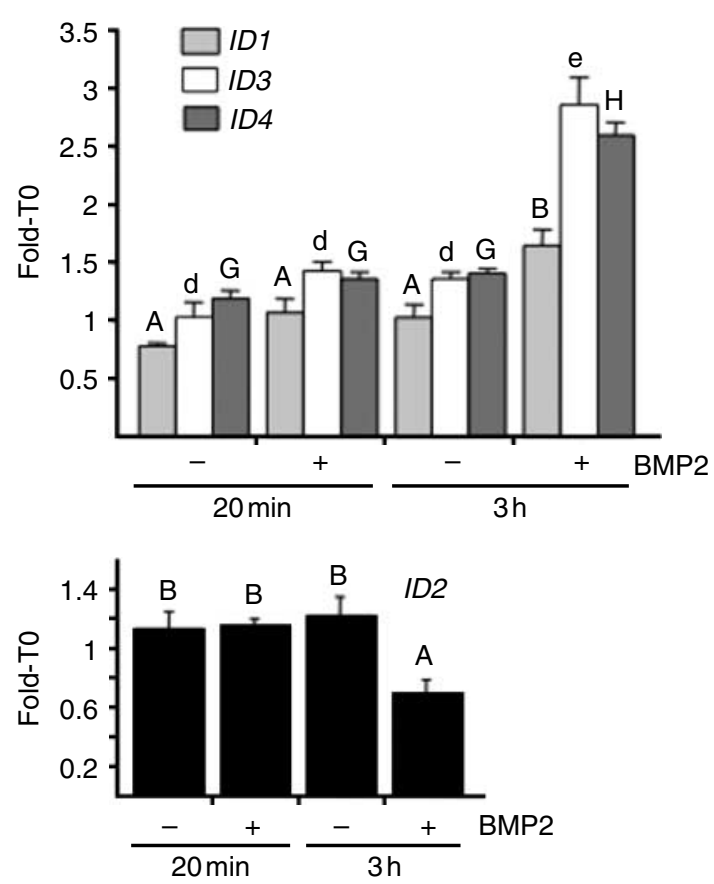

Figure 4 BMP2 treatment $(+; 10 \mathrm{ng} / \mathrm{ml}$ ) for $3 \mathrm{~h}$ induced ID1, ID3, ID4, and ID2 mRNA expression compared with control cultured (-) granulosa cells. Data are expressed as mean fold difference \pm s.E.M. compared to uncultured (T0) cells (not shown). $N=3$ replicate experiments. A, B; d, e; and G, H: $P<0.05$.

\section{Discussion}

Results demonstrate that BMP2 treatment, in vitro, blocks TGFB- and TGFB plus FSH-induced FSHR mRNA expression in undifferentiated granulosa cells from prehierarchal follicles (Fig. 2A). Based upon the data presented herein, a working model to describe the autocrine/paracrine effects of BMP2 on FSHR expression is described in Fig. 8.

The ability of BMP2-induced signaling to block FSHR expression in undifferentiated granulosa cells is similar to previous results related to EGFRL (e.g. BTC, EGF, and TGFA)-mediated inhibitory signaling via MAP kinase/ERK (Woods \& Johnson 2005, Woods et al. 2005). It is well established that BMP2 receptor signaling occurs via $\mathrm{SMAD} 1 / 5 / 8$, and there are various reports that BMP2 can also activate MAP kinase/ERK signaling in a latent and prolonged fashion (Lou et al. 2000, Lai \& Cheng 2002). Although we found no evidence for this in the present study, it is premature to dismiss the possibility for BMPinduced MAP kinase/ERK signaling in the hen granulosa cells. It is, however, notable that BMP2 treatment rapidly induced BTC and EGF mRNA expression (Fig. 3). This is noteworthy because treatment with BTC or TGFA was reported to increase ID1, ID3, and ID4 expression (and decrease levels of ID2) in undifferentiated granulosa cells (Johnson et al. 2008a). These effects on ID expression are completely blocked by treatment with the selective MAP kinase/ERK inhibitor, U0126. We have recently provided evidence that changes in ID protein expression can modulate FSHR mRNA expression in undifferentiated granulosa cells (Johnson et al. 2008a, Johnson \& Woods 2009). In the present studies, BMP2 treatment was found to increase ID1, ID3, and ID4 expression (Fig. 4), and this response (at $3 \mathrm{~h}$ ) occurred after the induced increase in BTC and EGF expression (at 20 min). Accordingly, BMP2 up-regulation of ID1, ID3, and ID4 may be mediated by EGFRL/MAP kinase/ERK signaling. This is supported by the finding that pretreatment with the selective ERBB tyrosine kinase inhibitor, AG1478, reversed the inhibitory effects of BMP2 on FSHR expression (Fig. 5).

It is also significant that BMP2 pretreatment also negatively impacted $\mathrm{FSH}$-induced progesterone production (Fig. 2B). Although it has not yet been established whether this loss of FSH responsiveness occurs prior and/or subsequent to CAMP formation, there is a recent report that BMP2 (and BMP4) inhibits both $\mathrm{FSH}$ - and forskolin-induced progesterone production and cAMP synthesis in rat granulosa cells (Inagaki et al. 2009). Importantly, highest levels of FSHR mRNA during follicle development occur in the hen granulosa cells from this cohort of prehierarchal follicles of 6-8 mm diameter (You et al. 1996, Woods \& Johnson 2005). Accordingly, it is evident that elevated FSHR mRNA (and presumably FSHR protein) by itself is not sufficient to initiate follicle selection and granulosa cell differentiation. It has previously been demonstrated that significant $\mathrm{FSH}$-induced CAMP production in granulosa cells occurs only subsequent to follicle selection (e.g. in 9-12 mm follicles; Tilly et al. 1991). Nevertheless, granulosa cells from follicles at all stages

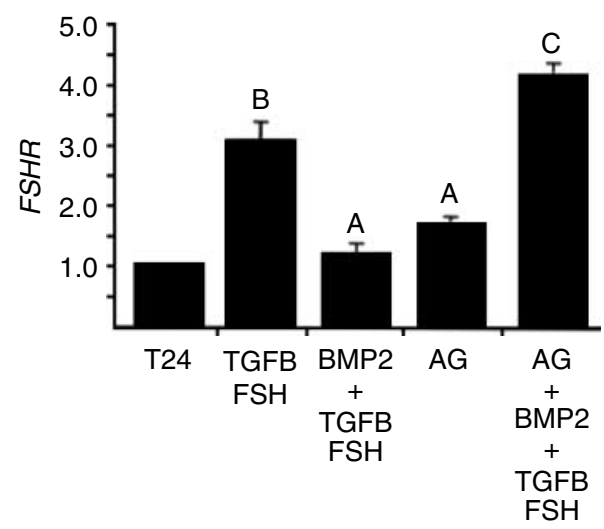

Figure 5 Inhibition of ERBB receptor kinase activity by pretreatment $(20 \mathrm{~min})$ with the selective inhibitor, $\mathrm{AG} 1478(\mathrm{AG} ; 10 \mu \mathrm{M})$, prevents the inhibitory effects of BMP2 $(10 \mathrm{ng} / \mathrm{ml})$ on TGFB $(10 \mathrm{ng} / \mathrm{ml})$ - and FSH $(100 \mathrm{ng} / \mathrm{ml})$-induced FSHR expression. Cells were precultured for $1 \mathrm{~h}$ with AG1478, and then treated with BMP2 for $3 \mathrm{~h}$ prior to TGFB plus FSH treatment. Data are expressed as mean fold difference \pm S.E.M. compared to control (T24) cultured cells. $N=3$ replicate experiments. $A, B$, and $C: P<0.05$. 

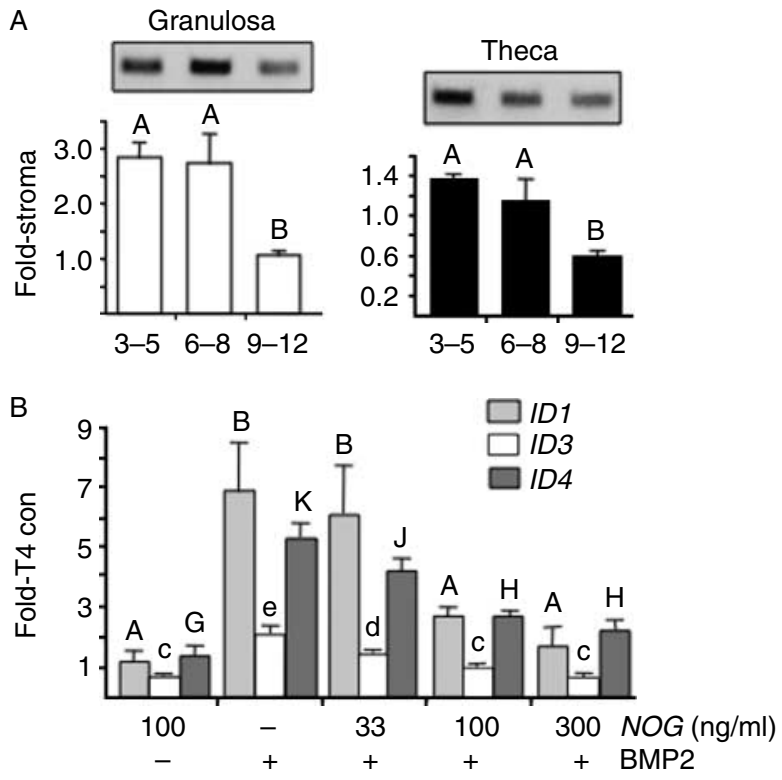

Figure 6 (A) NOG mRNA expression in granulosa and theca tissues collected from prehierarchal follicles of 3-5 and 6-8 $\mathrm{mm}$ diameter and the most recently selected $(9-12 \mathrm{~mm}$ ) follicle from three ovaries. Data are expressed relative to levels in ovarian stromal tissue (not shown). $\mathrm{A}$ and $\mathrm{B}: P<0.05$. (B) BMP2 (+; $25 \mathrm{ng} / \mathrm{ml})$-induced ID1, ID3, and ID4 mRNA expression is bioneutralized by a 20-min pretreatment with recombinant human NOG. Data represent the mean \pm s.E.M. from three replicate experiments. $\mathrm{A}, \mathrm{B} ; \mathrm{C}, \mathrm{d}, \mathrm{e}$; and $\mathrm{G}, \mathrm{H}, \mathrm{J}, \mathrm{K}: \bar{P}<0.05$.

of development (beginning with follicle 1-2 $\mathrm{mm}$ in diameter) are competent to respond, in vitro, to the cAMP analog, 8-bromo-cAMP, with a rapid and robust increase in STAR expression and cytochrome P450 side chain cleavage enzyme activity (Li \& Johnson 1993, Woods \& Johnson 2005). Collectively, these results observed from the hens provide evidence that prerequisite for the daily selection of a single follicle into the preovulatory hierarchy is: 1) a release from tonic inhibitory signaling within the granulosa layer of the selected follicle; 2) a consequent increase in FSHR mRNA expression mediated by enhanced responsiveness to TGFB and $\mathrm{FSH}$; combined with 3) a fully potentiated coupling of the FSHR protein to the protein kinase A/cAMP signaling pathway. Additional studies are required to understand the timing and mechanisms underlying FSHR coupling to cell signaling pathways in granulosa cells during early follicle development, together with the ability of EGFRLs and BMPs to modify this signaling.

In mammalian follicles, NOG is reported to bind several BMP family members produced by the theca, granulosa, and/or oocyte, including BMP2, -4, -5, -6, and -7 , but not by the oocyte-derived BMP15 or GDF9 (Gazzerro \& Canalis 2006). For instance, treatment with rh NOG effectively bioneutralized the inhibitory effects of BMP2 treatment on progesterone production by cultured ovine granulosa cells (Pierre et al. 2005). Similarly, in the present studies, NOG effectively reversed both the stimulatory effects of BMP2 on ID1, ID3, and ID4 expression (Fig. 6B) and the inhibitory actions of BMP2 on FSHR expression and progesterone production (Fig. 7). Each of these processes affected by NOG treatment reflects an endpoint associated with the differentiation in the hen granulosa cells. Thus, it is possible that the coordinated expression and secretion of NOG (or some other BMP2 antagonist) protein could play a role in follicle selection and/or the regulation of initial steroid production by the granulosa layer. For completeness, it is observed that there have been two novel NOG homologs reportedly encoded within the chicken genome (NOG2 and NOG4; Eroshkin et al. 2006). To date, however, there is apparently no information regarding patterns of expression or BMPbinding partners for these, or any other, BMP-specific antagonist in the hen granulosa cells.

Whereas a functional role of BMP15 in granulosa from preovulatory follicles has previously been proposed (Elis et al. 2007), the studies described herein provide some of the first functional data from the avian ovary to implicate BMP family members in the regulation of granulosa cell function during early follicle development. Significantly, the expression of, and a functional role for, another BMP-related protein, anti-Mullerian hormone $(\mathrm{AMH})$, has also been reported in the hen granulosa cells from prehierarchal follicles (Johnson et al. 2008b). In addition to its initially described role in the regression of the right Mullerian duct in females during embryonic development, $\mathrm{AMH}$ was shown to regulate granulosa cell proliferation and may be implicated in the rate of follicle growth and/or selection
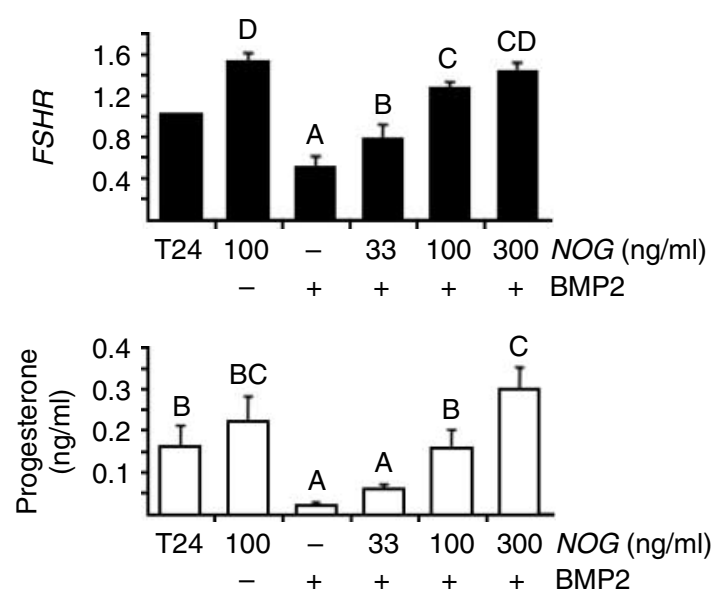

Figure 7 Bioneutralization of BMP2 $(25 \mathrm{ng} / \mathrm{ml})$ by a 20-min preculture with recombinant human NOG facilitates FSHR expression and progesterone accumulation in the medium over a 24-h culture period. FSHR data are expressed as fold difference compared to control (T24) cultured cells (not shown). $N=3$ replicate experiments. A, B, and C: $P<0.05$. 


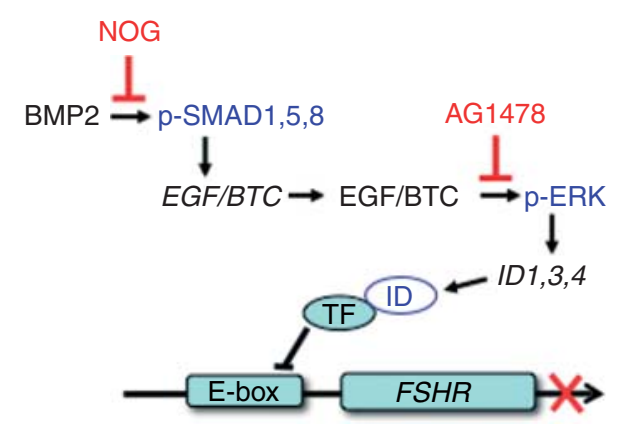

Figure 8 Working model for BMP2 inhibitory effects on FSHR mRNA expression in undifferentiated hen granuosa cells from prehierarchal follicles. BMP2 produced in a paracrine and/or autocrine fashion promotes phosphorylation ( $p$-) of SMAD1,5,8 and rapidly up-regulates expression of epidermal growth factor receptor ligand mRNAs (including EGF and BTC) and presumably proteins (EGF and BTC). In turn, EGF and BTC signal via ERBB-associated tyrosine kinase activation ( $p$-ERK) to up-regulate expression of the inhibitor of differentiation/DNA-binding proteins, ID1, ID3, and ID4. A requirement for ERBB/ERK signaling is indicated by the ability of AG1478 to block the inhibitory actions of BMP2. We have previously provided evidence that endogenous up-regulation of ID1, ID3, or ID4 protein is associated with inhibition of FSHR transcription in the hen granulosa cells (Johnson et al. 2008b), presumably via the disruption of transcription factor (TF) binding to one or more E-box element within the FSH receptor promoter region. The BMP antagonist, NOG, is also expressed within follicle tissues, and may serve as a paracrine and/or autocrine regulator of BMP2 activity during follicle development.

(Johnson et al. 2009). Additional functional studies that specifically focus on the role of these and related BMP family members in regulating $\mathrm{FSH}$ responsiveness and mediating follicle selection are warranted.

\section{Materials and Methods}

\section{Animals and reagents}

Single-comb White Leghorn hens $25-40$ weeks of age and laying sequences of six or more eggs on a regular basis were used in all studies described. Hens were housed individually in laying batteries, with free access to feed (Purina Layena Mash; Purina Mills, St Louis, MO, USA) and water, under a controlled photoperiod of $15 \mathrm{~h}$ light: $9 \mathrm{~h}$ darkness, (lights on at midnight). The lay patterns were monitored daily. Hens were killed by cervical dislocation $14-18 \mathrm{~h}$ prior to a mid-sequence ovulation, and the ovary was removed and placed in ice-cold sterile $1 \% \mathrm{NaCl}$ solution until granulosa cells were collected. All procedures described herein were reviewed and approved by the University of Notre Dame and the Pennsylvania State University Institutional Animal Care and Use Committees, and were performed in accordance with the Guiding Principles for the Care and Use of Laboratory Animals.

Rh FSH was provided by the National Hormone and Pituitary Program (Torrance, CA, USA), and rh BMP2, BTC, TGFB, and NOG were purchased from PeproTech (Rocky Hill, NJ, USA). The rh BMP2 peptide shares $96 \%$ identity with Gallus BMP2.
Gallus NOG protein is predicted to share $85 \%$ identity with the rh NOG, and the ability for rh NOG to inhibit endogenous BMP signaling in the chicken has previously been demonstrated (Schlueter et al. 2006). The selective ERBB1/ERBB4 receptor tyrosine kinase inhibitor, AG1478, was from Calbiochem (San Diego, CA, USA). The duration of culture experiments and doses of FSH, TGFB, and AG1478 utilized were based upon previously published studies (Woods et al. 2005, 2007, Johnson et al. 2008b).

\section{Granulosa cell cultures}

Prehierarchal follicles (3-5 and 6-8 $\mathrm{mm}$ diameter; prior to follicle selection) and the single, most recently selected follicle (9-12 mm) were utilized for the present studies. Granulosa cell layers were collected and grouped by follicle size, then dispersed for culture as described previously (Woods \& Johnson 2005). In some instances, an aliquot of cells was immediately frozen at $-70^{\circ} \mathrm{C}$ (T0 control). The remaining cells were cultured for 3 or $24 \mathrm{~h}$ at $40{ }^{\circ} \mathrm{C}$ in an atmosphere of $95 \%$ air: $5 \% \mathrm{CO}_{2}$ in 12-well polystyrene culture plates (Beckton Dickinson, Franklin Lakes, NJ, USA) with a density of $\sim 1 \times 10^{5}$ cells per well in $1 \mathrm{ml}$ DMEM plus $2.5 \%$ FBS containing $0.1 \mathrm{mM}$ non-essential amino acids plus $1 \%$ antibiotic-antimycotic mixture (Invitrogen; DMEM). In addition, 20-min incubations were conducted with granulosa from follicles of $6-8 \mathrm{~mm}$ diameter where $5 \times 10^{5}$ cells in $1 \mathrm{ml}$ DMEM were placed in $12 \times 75 \mathrm{~mm}$ polypropylene tubes (Fisher Scientific, Pittsburgh, PA, USA; Woods \& Johnson 2007). Where appropriate, cells were pretreated with $10 \mu \mathrm{M}$ AG1478 and/or BMP2, or with rh NOG, as described for each experiment.

\section{PCR amplification of BMP2 and NOG CDNA}

$B M P 2$ and NOG mRNA were amplified from follicle tissues using reverse-transcribed RNA (Promega RT System, Promega). Specific primers designed for Gallus BMP2 (GenBank NM_204358) were as follows: sense, 5'-AGCGAAACACAAACAGCGTAAGCG-3' and antisense, 5'-AGTTTAGGTGATCTGCCAGCGGAA-3'. Gallus NOG (GenBank NM_204123) primers were as follows: sense, $5^{\prime}$-TGCCAGCACTACCTGCACATCC- $3^{\prime}$ and antisense, 5'-AACTCCAGCCCCTTGATTTCGCCG- $3^{\prime}$. Amplification conditions included denaturing at $94^{\circ} \mathrm{C}$, annealing at $56^{\circ} \mathrm{C}$ (BMP2) or $55^{\circ} \mathrm{C}$ (NOG), and extension at $72{ }^{\circ} \mathrm{C}$ for $35-40$ cycles using Taq DNA polymerase (Eppendorf, Westbury, NY, USA). The PCR products were subsequently sequenced for verification of nucleic acid identity.

\section{Real-time PCR}

Forward and reverse primers specific for Gallus EGF, BTC, $F S H R$, ID protein isoforms (ID1, ID2, ID3, and ID4), and $18 S$ rRNA have previously been described (Woods \& Johnson 2007, Johnson et al. 2008a). Random-primed, reverse-transcribed CDNA synthesis reactions were performed using the Promega RT System (Promega), according to the conditions described by the manufacturer. For real-time PCR, primers were added to $10 \mu \mathrm{l}$ total reaction volume using the reagents provided in 
the ABgene QPCR SYBR Green Mix (ABgene, Rochester, NY, USA). Final concentrations of the sense and antisense primers were determined for each primer pair based upon optimal amplification efficiency. Reactions were completed on the $A B$ StepOnePlus Real-Time PCR System (Applied Biosystems, Carlsbad, CA, USA). Reactions were conducted with the following conditions: $15 \mathrm{~min}$ at $94{ }^{\circ} \mathrm{C}$, followed by 40 cycles each for $15 \mathrm{~s}$ at $95{ }^{\circ} \mathrm{C}, 1 \mathrm{~min}$ at either $55^{\circ} \mathrm{C}$ or $60{ }^{\circ} \mathrm{C}$ depending upon primer pair, and $1 \mathrm{~min}$ at $72{ }^{\circ} \mathrm{C}$. The $C_{\mathrm{t}}$ (the cycle number at which the fluorescence exceeds a threshold level) was determined for each reaction (run in triplicate) using the StepOne software (v.2.0), and quantification was accomplished by standardizing reactions to $18 \mathrm{~S}$ rRNA, then using the $\Delta \Delta C_{\mathrm{t}}$ method (Livak \& Schmittgen 2001). Results were expressed as fold difference compared to an appropriate control tissue or treatment.

\section{Progesterone RIA}

Progesterone in media samples was quantified by RIA as described previously (Tilly \& Johnson 1988). Data are expressed as mean nanogram progesterone/ml media \pm s.E.M. for the combined replicate experiments.

\section{Immunoblot analysis}

Western blot analysis was conducted as described previously (Johnson et al. 2008a). Briefly, cells were homogenized in a protein lysis buffer containing a cocktail of enzyme (including phosphatase) inhibitors (Sigma-Aldrich). The rabbit phospho-SMAD1 (Ser463/465)/SMAD5 (Ser463/465)/SMAD8 (Ser426/428) polyclonal antibody (Cell Signaling, Danvers, MA, USA) was used at a dilution of 1:1000, and a rabbit polyclonal anti-SMAD1 (Santa Cruz, Santa Cruz, CA, USA; diluted 1:1000) was used for standardization. Incubations for the primary antibodies were conducted overnight at $4{ }^{\circ} \mathrm{C}$. The HRP-conjugated anti-rabbit IgG secondary antibody (Pierce, Rockford, IL, USA) was incubated for $2 \mathrm{~h}$ at room temperature. Blots were incubated with ECL western blotting agent (Thermo Scientific, Rockford, IL, USA) for $5 \mathrm{~min}$ and exposed to X-ray film for 1-5 min. Antibody binding was quantified by densitometry (Storm Imaging system, Molecular Dynamics, Sunnyvale, CA, USA) and analyzed with ImageJ software (NIH).

\section{Data analysis}

Experiments were independently replicated a minimum of three times unless otherwise stated. Data for mRNA were expressed as a fold difference compared to uncultured control (T0) or control cultured (T24) cells. Real-time PCR data from replicate experiments were analyzed by one-way ANOVA without including values from the control group (arbitrarily set to 1.0) and by the Fisher's protected least significant difference multiple range test. Progesterone in media samples from the combined replicate experiments, including T24 controls, was analyzed by one-way ANOVA.

\section{Declaration of interest}

The authors declare that there is no conflict of interest that could be perceived as prejudicing the impartiality of the research reported.

\section{Funding}

This work was supported by the National Science Foundation (IOS 0968784) to A L Johnson.

\section{Acknowledgements}

We thank Dr D C Woods for valuable discussions and Dr O Ocon-Grove for technical assistance.

\section{References}

Al-Musawi SL, Gladwell RT \& Knight PG 2007 Bone morphogenetic protein- 6 enhances gonadotrophin-dependent progesterone and inhibin secretion and expression of mRNA transcripts encoding gonadotrophin receptors and inhibin/activin subunits in chicken granulosa cells. Reproduction 134 293-306. (doi:10.1530/REP-07-0070)

Davis AJ, Brooks CF \& Johnson PA 2001 Follicle-stimulating hormone regulation of inhibin $\alpha$ - and $\beta$ (B)-subunit and follistatin messenger ribonucleic acid in cultured avian granulosa cells. Biology of Reproduction 64 100-106. (doi:10.1095/biolreprod64.1.100)

Dong J, Albertini D, Nishimori K, Lu N \& Matzuk M 1996 Growth differentiation factor-9 is required during early ovarian folliculogenesis. Nature 383 531-535. (doi:10.1038/383531a0)

Elis S, Dupont J, Couty I, Persani L, Govoroun M, Blesbois E, Batellier F \& Monget P 2007 Expression and biological effects of bone morphogenetic protein-15 in the hen ovary. Journal of Endocrinology 194 485-497. (doi:10.1677/JOE-07-0143)

Eroshkin FM, Ermakova GV, Bayramov AV \& Zaraisky AG 2006 Multiple Noggins in vertebrate genome: cloning and expression of Noggin2 and Noggin4 in Xenopus laevis. Gene Expression Patterns 6 180-186. (doi:10.1016/j.modgep.2005.06.007)

Galloway SM, McNatty KP, Cambridge LM, Laitnen MPE, Jeungel JL, Jokiranta TS, McLauren RJ, Luiro K, Dodds KG, Montgomery GW et al. 2000 Mutations in an oocyte-derived growth factor gene (BMP-15) cause increased ovulation rate and infertility in a dose-sensitive manner. Nature 25 279-283. (doi:10.1038/77033)

Gazzerro E \& Canalis E 2006 Bone morphogenetic proteins and their antagonists. Reviews in Endocrine and Metabolic Disorders 7 51-65. (doi:10.1007/s11154-006-9000-6)

Heckert LL 2001 Activation of the rat follicle-stimulating hormone receptor promoter by steroidogenic factor 1 is blocked by protein kinase $\mathrm{A}$ and requires upstream stimulatory factor binding to a proximal $\mathrm{E}$ box element. Molecular Endocrinology 15 704-715. (doi:10.1210/me. 15.5.704)

Inagaki K, Otsuka F, Miyoshi T, Yamashita M, Takahashi M, Goto J, Suzuki J \& Makino H 2009 p38-Mitogen-activated protein kinase stimulated steroidogenesis in granulosa cell-oocyte co-cultures: role of bone morphogenetic proteins 2 and 4. Endocrinology 150 1921-1930. (doi:10.1210/en.2008-0851)

Johnson AL \& Bridgham JT 2001 Regulation of steroidogenic acute regulatory protein and luteinizing hormone receptor messenger ribonucleic acid in hen granulosa cells. Endocrinology 142 3116-3124. (doi:10.1210/en.142.7.3116)

Johnson AL \& Woods DC 2009 Dynamics of avian ovarian follicle development: cellular mechanisms of granulosa cell differentiation. General and Comparative Endocrinology 163 12-17. (doi:10.1016/j. ygcen.2008.11.012) 
Johnson AL, Bridgham JT \& Wagner B 1996 Characterization of a chicken luteinizing hormone receptor (cLH-R) cDNA, and expression of $\mathrm{cLH}-\mathrm{R}$ mRNA in the ovary. Biology of Reproduction 55 304-309. (doi:10.1095/ biolreprod55.2.304)

Johnson AL, Haugen MJ \& Woods DC 2008a Role for inhibitor of differentiation/deoxyribonucleic acid-binding (Id) proteins in granulosa cell differentiation. Endocrinology 149 3187-3195. (doi:10.1210/en. 2007-1659)

Johnson PA, Kent TR, Urick ME \& Giles JR 2008 $b$ Expression and regulation of anti-Mullerian hormone in an oviparous species, the hen. Biology of Reproduction 78 13-19. (doi:10.1095/biolreprod.107.061879)

Johnson PA, Kent TR, Urick ME, Trevino LS \& Giles JR 2009 Expression of anti-Mullerian hormone in hens selected for different ovulation rates. Reproduction 137 857-863. (doi:10.1530/REP-08-0406)

Knight PG \& Glister C 2006 TGF- $\beta$, superfamily members and ovarian follicle development. Reproduction 132 191-206. (doi:10.1530/rep.1. 01074)

Lai C-F \& Cheng S-L 2002 Signal transductions induced by bone morphogenetic protein- 2 and transforming growth factor- $\beta$ in normal human osteoblastic cells. Journal of Biological Chemistry 277 15514-15522. (doi:10.1074/jbc.M200794200)

Li Z \& Johnson AL 1993 Regulation of P450 cholesterol side-chain cleavage mRNA expression and progesterone production in hen granulosa cells. Biology of Reproduction 49 463-469. (doi:10.1095/biolreprod49.3.463)

Livak KJ \& Schmittgen TD 2001 Analysis of relative gene expression data using real-time quantitative PCR and the $2^{-\Delta \Delta C_{\mathrm{t}}}$ method. Methods 25 402-408. (doi:10.1006/meth.2001.1262)

Lou J, Tu Y, Li S \& Manske PR 2000 Involvement of ERK in BMP-2 induced osteoblastic differentiation of mesenchymal progenitor cell line C3H10T1/2. Biochemical and Biophysical Research Communications 268 757-762. (doi:10.1006/bbrc.2000.2210)

Lovell TM, Gladwell RT, Groome NP \& Knight PG 2003 Ovarian follicle development in the laying hen is accompanied by divergent changes in inhibin $\mathrm{A}$, inhibin $\mathrm{B}$, activin $\mathrm{A}$ and follistatin production in granulosa and theca layers. Journal of Endocrinology 177 45-55. (doi:10.1677/joe.0. 1770045)

Onagbesan OM, Bruggeman V, Van As P, Tona K, Williams J \& Decuypere E 2003 BMPs and BMPRs in chicken ovary and effects of BMP-4 and-7 on granulosa cell proliferation and progesterone production in vitro. American Journal of Physiology. Endocrinology and Metabolism 285 E973-E983. (doi:10.1152/ajpendo.00104.2003)

Otsuka F, Yamamoto S, Erickson GF \& Shimasaki S 2001 Bone morphogenetic protein-15 inhibits follicle-stimulating hormone (FSH) action by suppressing FSH receptor expression. Journal of Biological Chemistry 276 11387-11392. (doi:10.1074/jbc.M010043200)

Pierre A, Pisselet C, Monget P, Monniaux D \& Fabre S 2005 Testing the antagonistic effect of follistatin on BMP family members in ovine granulosa cells. Reproduction, Nutrition, Development 45 419-425. (doi:10.1051/rnd:2005031)
Ruzinova MB \& Benezra R 2003 Id proteins in development, cell cycle and cancer. Trends in Cell Biology 13 410-418. (doi:10.1016/S09628924(03)00147-8)

Schlueter J, Manner J \& Brand T 2006 BMP, is an important regulator of proepicardial identity in the chicken embryo. Developmental Biology 295 546-558. (doi:10.1016/j.ydbio.2006.03.036)

Shi J, Yoshino O, Osuga Y, Koga K, Hirota Y, Hirata T, Yano T, Nishii O \& Taketani Y 2009 Bone morphogenetic protein-6 stimulates gene expression of follicle-stimulating hormone receptor, inhibin/activin $\beta$ subunits, and anti-Müllerian hormone in human granulosa cells. Fertility and Sterility 92 1794-1798. (doi:10.1016/j.fertnstert.2009.05.004)

Sudo S, Avsian-Kretchmer O, Wang LS \& Hsuek AJW 2004 Protein related to DAN and cerberus is a bone morphogenetic protein antagonist that participates in ovarian paracrine regulation. Journal of Biological Chemistry 279 23134-23141. (doi:10.1074/jbc.M402376200)

Tilly JL \& Johnson AL 1988 Attenuation of hen granulosa cell steroidogenesis by a phorbol ester and 1-oleoyl-2-acetylglycerol. Biology of Reproduction 39 1-8. (doi:10.1095/biolreprod39.1.1)

Tilly JL, Kowalski KI \& Johnson AL 1991 Stage of follicular development associated with the initiation of steroidogenic competence in avian granulosa cells. Biology of Reproduction 44 305-314. (doi:10.1095/ biolreprod44.2.305)

Woods DC \& Johnson AL 2005 Regulation of follicle-stimulating hormonereceptor messenger RNA in hen granulosa cells relative to follicle selection. Biology of Reproduction 72 643-650. (doi:10.1095/biolreprod.104.033902)

Woods DC \& Johnson AL 2007 Protein kinase C activity mediates LH-induced ErbB/Erk signaling in differentiated hen granulosa cells. Reproduction 133 733-741. (doi:10.1530/REP-06-0261)

Woods DC, Haugen MJ \& Johnson AL 2005 Opposing actions of TGF $\beta$ and MAP kinase signaling in undifferentiated hen granulosa cells. Biochemical and Biophysical Research Communications 336 450-457. (doi:10.1016/j.bbrc.2005.08.107)

Woods DC, Haugen MJ \& Johnson AL 2007 Actions of epidermal growth factor receptor/mitogen-activated protein kinase and protein kinase $C$ signaling in granulosa cells from Gallus gallus are dependent upon stage of differentiation. Biology of Reproduction 77 61-70. (doi:10.1095/ biolreprod.106.059394)

You S, Bridgham J, Foster DN \& Johnson AL 1996 Characterization of the chicken follicle-stimulating hormone receptor (cFSH-R) complementary deoxyribonucleic acid, and expression of cFSH-R messenger ribonucleic acid in the ovary. Biology of Reproduction 55 1055-1062. (doi:10.1095/ biolreprod55.5.1055)

Received 6 May 2010

First decision 23 June 2010

Accepted 16 July 2010 